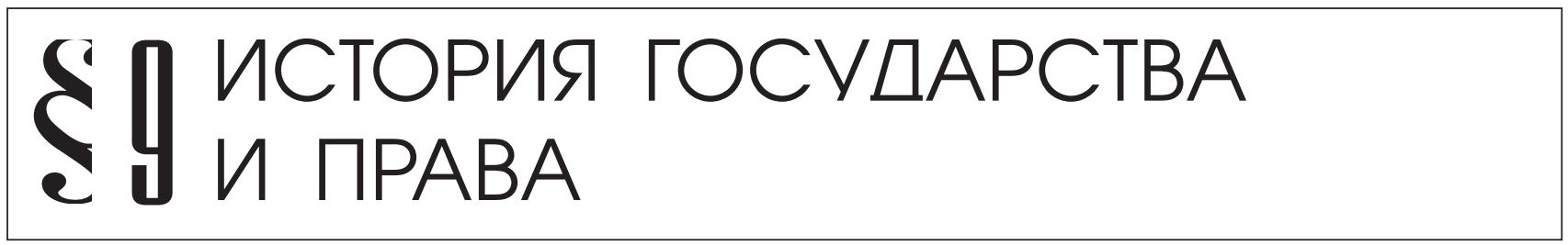

Верещагина A.B.

\title{
НАЗНАЧЕНИЕ УГОЛОВНОГО СУДОПРОИЗВОДСТВА: РЕТРОСПЕКТИВА ТЕОРЕТИЧЕСКОГО ОБОСНОВАНИЯ И ЛЕГАЛЬНОГО ЗАКРЕПЛЕНИЯ
}

\begin{abstract}
Аннотация: Статья посвящена назначению уголовного судопроизводства. Автор излагает историю развития теоретического обоснования назначения уголовного процесса в дореволюиионный и советский периоды. В публикации представлен анализ нормативной регламентации задач уголовного судопроизводства дореволюиионного и советского периодов. Трансформация теоретического обоснования и легального закрепления назначения уголовного процесса представлена через призму сочиально-политического контекста. В работе дана периодизация (выделено два этапа) развития теоретических представлений и легального закрепления цели уголовного процесса в советский период. Исследование базируется на принципах научного познания: историзме, объективности, системности, развитии и плюрализме. Особенности предмета исследования обусловили наиболее активное использование исторического, системно-структурного и формально-логического методов познания. Научная новизна исследования заключается в том, что автор предпринял попытку представить тенденции развития как теоретического обоснования, так и легального закрепления назначения уголовного судопроизводства, на содержание которых по его мнению влияет соииально-политический контекст. В результате исследования сформулирован вывод о том, что советское теоретическое и легальное понимание назначения уголовного судопроизводства выкристаллизовалось к кониу 50-х годов ХХ века.
\end{abstract}

Ключевые слова: Законодательство, правосудие, уголовный прочесс, история уголовного прочесса, назначение уголовного процесса, публичный аспект назначения, частный аспект назначения, дореволюиионный уголовный прочесс, советский уголовный прочесс, реформа уголовного процесса.

Abstract: This article is dedicated to the purpose of criminal procedure. The author presents the history of the development of theoretical substantiation of the purpose of criminal procedure in the pre-revolution and Soviet periods. The article delivers the analysis of the normative regulation of the tasks of criminal procedure during the pre-revolutionary and Soviet periods. The transformation of theoretical substantiation and legal support of the purpose of criminal procedure is offered through the prism of socio-political context. The work provides periodization (highlighting two stages) of the development of theoretical perceptions and legal support of the purpose of criminal procedure during Soviet era. The scientific novelty consists in the author's attempt to present the trends of development of the theoretical substantiation, as well as the legal support of the purpose of criminal procedure, the content of which (in the author's opinion) is affected by the socio-political context. As a result of the research, a conclusion is formulated that the Soviet theoretical and legal understanding of the purpose of criminal procedure was taking shape towards the end of the 1950's.

Keywords: Pre-revolutionary criminal procedure, private aspect of purpose, public aspect of purpose, purpose of criminal procedure, criminal procedure history, criminal procedure, justice, legislation, Soviet criminal procedure, criminal procedure reform.

аверное, одну из первых попыток легального закрепления назначения уголовного судопроизводства в России (автор, исходя из семантики слов «задача», «цель», «назначение», использует их в тексте статьи как тождественные) предприняли в Кратком изображении процессов или судебных тяжеб: «Процесс есть дело судимое, через который случающиеся тяжебные дела основательным представлением, и из обстоятельств дел обретенных доказов явные сочиняются, и потом от Судей, по изобретению оных причин, решение чинится» (пункт 1 главы II «О процессе или тяжбе») [1]. Иными словами под назначением процесса в этом акте понимается рассмотрение дела судом и принятие по нему реше- 
DOI: $10.7256 / 1811-9018.2015 .9 .16032$

При цитировании этой статьи сноска на dоі обязательна

История государства и права

ния на основании собранных доказательств, то есть процесс - способ разрешения спора.

В это же время появляются исследования, касающиеся желательной организации суда и отправления правосудия.

Одно из таких сочинений принадлежало И.Т. Посошкову. Почти триста лет назад он видел назначение судопроизводства в справедливом разрешении спора и ограждении личности от необоснованного уголовного преследования - «суд правдив судити, дабы от незнания своего правого не обвинити, а виновного не оправити» [2, с. 55]. Эта формулировка сопоставима с имеющимся легальным пониманием назначения уголовного судопроизводства, закрепленным в статье 6 УПК РФ 2001 года [3].

В течение XVIII-го столетия вопросы правосудия постоянно интересуют представителей российского гражданского общества. Например, российский баснописец и драматург Д.И. Фонвизин, под сущностью правосудной деятельности понимал разрешение дел в соответствии с законом. Деятельность суда и судьи, по его мнению, подзаконна («правосудие определено награждать и наказывать сходственно с законом»; «судья не властен внимать правоте своей, а повинен следовать правосудию, то есть закону») [4, с. 146; 5, с.65-73].

С момента своего зарождения теоретическая юриспруденция, толчком к развитию которой послужило открытие Московского университета в 1755 году, также всегда касалась вопросов организации и деятельности суда. В этой связи нельзя не упомянуть работ С.Е. Десницкого - первого профессора права «из природных россиян», предлагавшего создать суд, который бы судил в точном соответствии с законами [6, с. 292-332].

В основе представлений о назначении уголовного судопроизводства в XIX веке лежит двойственная природа права, на которую указывали зарубежные и российские ученые. Так, зачинатель исследований в области философии права в России К.А. Неволин писал, что закон закрепляет права и обязанности и меры для их защиты («охранения») [7, с.44]. Профессором К.А. Неволиным почти дословно воспроизведена мысль его учителя М.М. Сперанского: «Закон суть правила, по коим ... государства действуют о охранении лица, чести и имущества народного» [8, с.42]. Словом, правила, установленные государством, обязательны для самого государства, которое должно действовать в их рамках.

Эта двойственность - квинтэссенция уголовного судопроизводства, поскольку его осуществление направлено одновременно на защиту интересов неопре- деленного круга лиц (публичный аспект) и прав и интересов субъекта, в отношении которого осуществляется уголовное преследование (частный аспект).

В русле этой идеи профессор Я.И. Баршев определяет уголовный процесс как способ «охранения» закона. Назначение («высшее и коренное начало») уголовного судопроизводства это правдивое осуществление и приведение в действие уголовных законов. При этом им чётко обозначены два важных момента. Во-первых, взаимная обусловленность судоустройства и уголовного судопроизводства для достижения целей последнего. Судоустройство обеспечивает «лёгкость» в установлении виновного и щадящее отношение к подсудимому, к которому принуждение применяется ровно настолько, насколько это необходимо «при следовании к цели уголовного судопроизводства». Во-вторых, двойственность назначения уголовного судопроизводства, заключается в «открытии» виновного и его наказании соразмерном деянию и «в возможной неприкосновенности» безвинного [9, с. 42].

Несколько позже профессор В.А. Линовский формулирует цели уголовного следствия (досудебного производства) и рассмотрения уголовного дела судом. Для уголовного следствия - это раскрытие преступлений, а для суда квалификация действий виновного и постановление правосудного приговора («...в возможно полную известность все обстоятельства, которые обусловливают приложение уголовного закона к известному случаю и на основании которых можно сделать решительный приговор, т.е. обвинительный, или освобождающий совершенно, или только в известном отношении»; «подвести под надлежащий закон те признаки, которые открыты в следствии» и постановить приговор, «который должен основываться на доказательствах не сомнительных и который должен удовлетворять началам правды и справедливости...») [10, с. 61, 156].

Таким образом, Я.И. Баршев и В.А. Линовский понимали уголовный процесс как процедуру разрешения уголовно-правового спора в соответствии с законами и на началах справедливости и правды. Кроме этого, профессором В.А. Линовским разграничиваются цели досудебного и судебного производства.

Понимание назначения уголовного судопроизводства российских представителей гражданского общества, законодателей и исследователей XIX века соответствовало подходам, сложившимся за рубежом.

По мнению И. Бентама судебные учреждения есть «средство для сообщения законам действительности» и их главной обязанностью («первой обязанностью») является «верность закону», т.е. «...точное исполне- 
DOI: $10.7256 / 1811-9018.2015 .9 .16032$

При цитировании этой статьи сноска на доі обязательна

\section{Право и политика 9 (189) $\bullet 2015$}

ние обещаний закона в отношении к каждому лицу». «Верность закону» «...составляет правоту судебных решений, и эта правота есть великая и главная цель, к которой в отправлении суда все должно быть направлено» $[11$, с. 3,4$]$. Из приведённых положений следует, что сущность уголовно-процессуальной деятельности это разрешение спора по существу в соответствии с законом, «счастливым результатом» которого, как считает И. Бентам, является общественное доверие.

Сложившееся представление о назначении уголовного судопроизводства содержится в концептуальном документе, предшествовавшем Судебным уставам 1864 года,-Основных положениях преобразования судебной части в России [12]. Согласно статье 5 этого акта судам принадлежит «власть судебная, т.е. рассмотрение уголовных дел и постановление приговоров». Безусловно, предполагалось разрешение уголовных дел в соответствии с законом. Как видно из этой формулировки никаких других задач «отцы судебной реформы» перед судом не ставили.

В трудах российских процессуалистов второй половины XIX - начала XX века означенный выше подход доминирует.

Сенатор, профессор И.Я. Фойницкий характеризовал уголовный процесс как процедуру рассмотрения публичного иска, в рамках которого происходит судебное признание принадлежащего государству права на наказание [13, с.1-2].

Аналогично назначение уголовного судопроизводства по С.И. Викторскому. Он определяет его, как правила, которыми «следует руководиться» при решении вопросов о наличии факта преступления, причастности к его совершению конкретного лица и возможности применения в отношении него наказания [14, с. 232].

При первом приближении несколько иначе подходит к «основной идее» уголовного судопроизводства И.В. Михайловский, по мнению которого в каждом уголовном деле должна быть установлена истина. На эту мысль И.В. Михайловского, вырванную из контекста, ссылаются некоторые современные сторонники советского понимания назначения уголовного процесса как процедуры, нацеленной на раскрытие преступлений и установление материальной истины. Однако развивая свою идею, И.В. Михайловский акцентирует - истина устанавливается определенными процессуальными средствами. К ним он относит процессуальное равенство сторон, право на защиту в формальном смысле, соблюдение правил доказывания, и принятие решения на основе исследованных в судебном заседании фактов по внутреннему убеждению судьи $[15$, с.6,7]. Очевидно, что И.В. Михайловский, пишет о формальной, а не материальной истине, поскольку делает упор на соблюдение процедуры, особенно, правил, обеспечивающих процессуальное равенство сторон в исследовании доказательств.

Сложно определить точную дату отказа российской юриспруденции от традиционного определения цели уголовного процесса.

В советский период в формировании нового теоретического обоснования и легального закрепления назначения уголовного судопроизводства можно выделить два этапа и две - политическую и собственно правовую составляющие, реализовывавшиеся сначала через самостоятельные организационные структуры соответственно трибунал и суд.

На первом этапе (1917-1922 год) задачи уголовной юстиции преимущественно формулировались в политических документах. Они чётко увязывались с первоочередными проблемами, решавшимися государством в тот или иной период. Зримо обозначена связь политических установок и задач суда М.В. Кожевниковым [16]. В разное время это были: 1) мародерство, саботаж и прочие злоупотребления торговцев, промышленников, чиновников; 2) злоупотребление «положением по государственной или общественной службе», которое нарушает «правильный ход работ в учреждении или предприятии»; 3) прекращение или сокращение производства «предметов массового потребления без действительной к тому необходимости»; 4) взяточничество; укрепление трудовой дисциплины [17, с. $51 ; 18$, ст. $8 ; 19$, ст. $1 ; 20] ; 5)$ «хищничество» («В целях борьбы с усилившимися хищениями с государственных складов и борьбы с должностными преступлениями лиц, способствующих по своему служебному положению указанным хищениям ...всем Губернским Революционным Трибуналам ...установить, как общее правило, применение строгой изоляции на срок не ниже трех лет и высшей меры наказания при отягчающих обстоятельствах...» [21, ст.1]; 6) волокита («Впредь привлекать к законной ответственности и карать по приговору народных судов всех лиц, виновных...» в волоките) [22, ст. 3] и т.п. На первом этапе формирования советской модели уголовной юстиции эти указания о наиболее важных, требовавших пристального внимания, вопросах, содержались в статьях лидеров партии, партийных документах, специальных декретах, посвящённых им, и предназначенных преимущественно квазисудебным органам - трибуналам, оперативно, в упрощённом процессуальном режиме реализовывавших политические директивы. 
DOI: $10.7256 / 1811-9018.2015 .9 .16032$

При цитировании этой статьи сноска на dоі обязательна

История государства и права

В последующем (второй этап - с 1922 года до конца 80-х годов XX века) в связи с укреплением «вовне и внутри» Советской власти трибуналы постепенно упразднялись, судебную систему унифицировали и борьбу с нарушением законов возложили на суды [23; 24]. Политические установки стали составляющей правовой основы, прежде всего организации, а затем деятельности судов.

В этот период появляются теоретические рассуждения о многообразии решаемых в уголовном судопроизводстве задач. Так, жарко полемизируя с Н.Н.Полянским, который тогда ещё придерживался взгляда на уголовный процесс как процедуру разрешения уголовно-правового спора, А.С. Тагер (1924 год) противопоставляет монизму Н.Н. Полянского телеологический плюрализм в определении целей уголовного процесса. По его мнению, «процессу можно и должно ставить не одну, а несколько целей. ... не все процессуальные институты преследуют одну и ту же цель; наоборот различным процессуальным институтам поставлены различные процессуальные цели, одной из таких целей является общая с уголовным правом цель борьбы с преступностью» [25, с. 53].

Представляется, что рассуждения А.С. Тагера о различных целях различных процессуальных институтов основаны на дефекте дореволюционной конструкции уголовного судопроизводства, которая включала в себя досудебную подготовку материалов уголовного дела, гипертрофированную впоследствии в советском уголовно-процессуальном законодательстве.

Уже к концу 20-х годов ХХ века один из ведущих советских процессуалистов М.С. Строгович цель деятельности судебно-следственных органов обозначает как выявление социально-опасных деяний (преступлений) и социально-опасных лиц, для применения к ним норм материального уголовного права для их «парализования» мерами социальной защиты (наказания). Критикуя буржуазных ученых, М.С. Строгович замечает, что «их туманные формулировки недостаточно вскрывают строго-публичный целевой характер уголовного процесса...наиболее успешную борьбу с преступлениями» [26, с.95]. Как видно из приведённого М.С. Строгович отождествляет уголовный процесс и розыскную деятельность, а использование термина «судебно-следственные органы» указывает на признание суда одним из органов, который борется с преступностью. Критикуя отмеченное выше двойственное понимание природы уголовного процесса (сочетание публичного и частного начал), влекущее его неустойчивость, поскольку равновесие нарушается в ту или другую сторону, М.С. Строгович отрицает в советском уголовно-процессуальном праве это противоречие. Защита общества от преступлений по его мнению не находится в противоречии с гарантиями прав и свобод личности. Напротив, защищаясь от преступлений, государство заинтересовано в защите от действительных преступлений и преступников. Наделяя личность правами, государство предоставляет ей возможность реализовывать эти права, пока это способствует достижению материальной истины по уголовному делу, т.е. это одно из средств её достижения [26, с. 100]. Идентифицируя уголовный процесс 20-х годов как смешанный, М.С. Строгович активную роль советского суда в судебных стадиях объясняет утилитарным характером роли сторон в судебных стадиях - их роль это роль помощников суда в отыскании материальной истины и реализации судом публичной функции [26, с. 106].

Совокупность доводов М.С. Строговича - это теоретическое обоснование восстановления инквизиционного процесса в советский период, когда суд реализует все процессуальные функции, а в двоякой цели уголовного судопроизводства подавляющей становится её публичный аспект. Право на защиту у обвиняемого предполагается, но исключительно в публичных интересах как одно из средств их достижения.

Концентрированно идея объединения всех процессуальных функций у одного субъекта, а, следовательно, восстановление инквизиционного процесса,

была выражена А.А. Сольцем в прениях по докладу Н.В. Крыленко о реформе советского уголовного процесса. «...в самом процессе судья должен защищать интересы населения, и когда он разбирает дело, ему не нужно ни обвинителя, ни защитника. ... будет полезнее если судья значительную часть своего времени потратит на непосредственное ознакомление с делом, вместо того, чтобы слушать две стороны, против которых он, естественно, предубежден» (курсив мой - А.В.) [27, с. 74-75].

Политико-публичную направленность деятельности юстиции в советский период и, с этой точки зрения, её основное назначение очень чётко сформулировал П.П. Постышев, писавший об изменчивости методов работы советской юстиции, в которых сочетание убеждения и принуждения не могут оставаться неизменными. «Они менялись и меняются на каждом новом этапе в соответствии с новой обстановкой, новыми задачами пролетарского государства» [28, с.9]. Классовая борьба основное назначение юстиции. Судья должен «искать в каждом правонарушении классовое (курсив мой-А.В.) содержание преступления...» [28, с. 10]. 
DOI: $10.7256 / 1811-9018.2015 .9 .16032$

При цитировании этой статьи сноска на доі обязательна

\section{Право и политика $9(189) \cdot 2015$}

В дальнейшем изложенное выше назначение уголовного судопроизводства исследователями не подвергалось сомнению. Профессор Н.Н. Полянский, хотя и указывает на то, что суд «разбирает дело в особом для суда установленном законом порядке и разрешает его на основании существующих норм права» [29, с.61], но далее в цитируемой работе, переносит акцент на публичные аспекты процесса. Он подчеркивает, что «советский суд, служа делу советского строительства, наказывает преступников, посягающих на Советское государство, на социалистический правопорядок и права и интересы граждан, принуждает к соблюдению закона, разрешает споры по существу о праве и утверждает...социалистическую законность» [29, с.62].

В работе, которая, как и статья Н.Н. Полянского, опубликована в 1947 году, И.Д. Перлов предлагает закрепить в проекте Уголовно-процессуального кодекса СССР в качестве задач уголовного процесса «раскрытие преступления, выявление лиц, повинных в совершении преступления, подлежащих наказанию, согласно законам СССР, и постановление приговора в отношении преданных суду лиц» [30, с. 44]. В числе задач И.Д. Перлов не указывает защиту прав уголовно-преследуемой личности. Это не означает, что она проигнорирована. Он рассматривает её как одно из средств, обеспечивающих провозглашение справедливого приговора, что в свою очередь способствует «улучшению борьбы с преступностью в интересах Советского государства и советского народа, будет способствовать изживанию случаев необоснованного привлечения к уголовной ответственности, необоснованного предания суду и необоснованного осуждения» [30, с. 44].

Двузначность уголовного судопроизводства И.Д. Перловым, как и М.С. Строговичем, не отрицается. Однако вслед за М.С. Строговичем, он в соответствии с господствовавшей идеологией идее защиты прав личности придаёт второстепенный, вспомогательный, по отношению к борьбе с преступностью и защитой государственных интересов, характер.

Изложенные выше точки зрения М.С. Строговича, А.А. Сольца, Н.Н. Полянского, П.П. Постышева и И.Д. Перлова свидетельство полного отказа рассматривать защиту прав личности, в отношении которой осуществляется уголовное преследование, в качестве задачи уголовного процесса. Обращает на себя внимание, что А.А. Сольц, хотя и ратует за полный отказ от участия защиты и обвинения в рассмотрении дел и тем самым фактически за восстановление инквизиционного процесса, но исходит всё-таки из того, что судья занимается «защитой на- селения». Спустя всего лишь 4 года П.П. Постышев призывает судей в каждом рассматриваемом преступлении искать, прежде всего, классовое содержание.

В период развитого социализма борьба с преступностью, как основная цель уголовного судопроизводства, не подвергалась сомнению.

Квинтэссенция такого подхода содержится в работе П.С. Элькинд, посвященной целям уголовного судопроизводства. В качестве перспективной цели уголовного процесса она рассматривает искоренение преступности как одно «из необходимых условий коммунистического строительства». К ближайшим целям, которые содействуют достижению цели перспективной, ею отнесены быстрое и полное раскрытие преступлений, изобличение виновных, обеспечение правильного применения закона с тем, чтобы каждый, совершивший преступление, был подвергнут справедливому наказанию, и ни один невиновный не был привлечен к уголовной ответственности [31, с. 39-40]. По другим, предложенным ею классификациям, всё перечисленное выше относится к общим и официальным целям. Неофициальные цели, под которыми П.С. Элькинд понимает «личный интерес тех или иных субъектов уголовного судопроизводства», являются неправомерными. Правда при этом, она, вероятно опасаясь быть превратно понятой и начисто лишить обвиняемого возможностей для защиты, например, путём отказа от дачи показаний, подчёркивает, что хотя его деятельность противоречит официальным целям, но не должна пресекаться как неправомерная [31, c.57-58].

Теоретические, политически выверенные выводы о назначении уголовного судопроизводства до конца 50-х годов XX века регламентировались в конституционных и судоустройственных, и лишь с принятием Основ уголовного судопроизводства 1958 года и в уголовно-процессуальных актах.

В Конституциях РСФСР 1918 и 1925 года не было положений судоустройственного и судопроизводственного характера, они появились только в союзной Конституции 1924 года, которая определяла цель деятельности учреждавшегося Верховного Суда СССР - «утверждение революционной законности на территории» СССР (ст. 43) [32; 33; 34].

В Конституциях СССР 1936 [35, ст. 102, 111, 112, 127, 128] и 1977 года [36, ст. 151, 155-158, 160] и Конституциях РСФСР 1937 [37, ст. 107, 115, 116] и 1978 года [38, ст. $163,167,168,169,170,172,173]$ под сущностью деятельности судов понималось отправление правосудия независимыми, подчиняющимися только закону, судьями путём гласного коллегиального рассмотрения 
различных категорий дел, в том числе уголовных. Декларировались обеспечение права обвиняемого на защиту, неприкосновенность личности и жилища, соблюдение тайны переписки. Помимо этих начал в Конституциях СССР и РСФСР соответственно 1977 и 1978 года закреплялась презумпция невиновности [35; 36 ]. Приведенные положения не несут явной политической окраски. Может сложиться впечатление, что понимание назначения уголовного процесса вполне соответствует дореволюционному подходу. Но, исходя из структуры Конституций 1936, 1937, 1977 и 1978 года, расставленных в них приоритетов в триаде личностьобщество-государство, можно смело утверждать, господствовал публичный интерес, хотя права и свободы личности декларировались.

Иным образом регламентируется назначение деятельности судов в законах и подзаконных актах, в них политическая классово-государственная составляющая является доминантой. Причём по мере удаления от дореволюционного периода она усиливается.

Положение о народном суде 1920 года норм о назначении деятельности судов не закрепляло [39]. В Положении о судоустройстве 1922 года достаточно чётко закреплялось двузначное, хотя и классово окрашенное, назначение деятельности судов: «В целях ограждения завоеваний пролетарской революции, обеспечения интересов государства, прав трудящихся и их объединений...» (ст.1) [40].

Основы судоустройства 1924 года детализируют и дополняют задачи, зафиксированные в Положении о судоустройстве 1922 года. К ним отнесены: «а) ограждение завоеваний пролетарской революции, рабоче-крестьянской власти и правопорядка, ею установленного; б) защита интересов и прав трудящихся и их объединений; в) укрепление общественно-трудовой дисциплины и солидарности трудящихся и их правовое воспитание; г) осуществление революционной законности в личных и имущественных отношениях граждан» (ст.1) [41]. Таким же образом сформулированы задачи суда в ст. 1 Положения о судоустройстве РСФСР 1926 года [42].

В статье 2 Закона о судоустройстве 1938 года обозначены следующие задачи правосудия: «защита от всяких посягательств» а) установленного конституционными актами «общественного и государственного устройства СССР, социалистической системы хозяйства и социалистической собственности»; б) гарантированных конституционными актами «политических, трудовых, жилищных и других личных и имущественных прав и интересов граждан СССР»; в) «прав и охраняемых законом интересов государственных учреждений, предприятий, колхозов, кооперативных и иных общественных организаций» [43].

Сопоставление норм статьи 1 Положения 1922 года, статьи 1 Основ 1924 года и статьи 2 Закона о судоустройстве 1938 года выявляет тенденцию развития регламентации назначения уголовного судопроизводства. В статье 1 Положения 1922 года и статье 1 Основ 1924 года, несмотря на революционно-романтическую терминологию, содержание задач преимущественно сводится к защите прав и свобод личности, обеспечению законности в личных и имущественных отношениях граждан, правопорядку, пусть и революционному, и правовому воспитанию трудящихся. Только одна из четырёх задач статьи 1 Основ 1924 года касается защиты завоеваний пролетарской революции и рабоче-крестьянской власти. Напротив, в статье 2 Закона о судоустройстве 1938 года акцент смещён на защиту государственного и общественного устройства, социалистической системы хозяйства и социалистической собственности и прав и законных интересов государственных органов и социалистических предприятий и колхозов.

По мере отдаления от дореволюционного прошлого и укоренения большевиков у власти задача защиты прав личности в уголовном процессе становится все менее и менее важной на фоне масштабных задач строительства социализма и защиты его экономической основы - coциалистической собственности. Все это в соответствии с тогдашней фразеологией осуществлялось, прежде всего, в интересах общественного и государственного устройства, а уже затем в интересах советских граждан.

В принятых в конце 50-х годов XX века нормативно-правовых актах применительно к назначению уголовного судопроизводства появились новые моменты. Во-первых, имевшаяся в этих нормативно-правовых актах терминологическая непоследовательность породила «бесплодную дискуссию» [44, с.16] о соотношении понятий «цель» и «задача» уголовного судопроизводства. Во-вторых, задачи уголовного судопроизводства закрепляются непосредственно в уголовно-процессуальном законодательстве. Важно отметить, что до конца 50 -х годов XX века норм о назначении уголовного судопроизводства уголовно-процессуальное законодательство не содержало [45; 46; 47]. В-третьих, легальное закрепление получила идея использования уголовного судопроизводства как средства борьбы с преступностью.

В Основах законодательства о судоустройстве 1958 года практически дословно воспроизведены задачи правосудия из Закона о судоустройстве 1938 года (ст.2,3). При этом они разделены на цели и задачи (соответственно ст. 2 и ст.3). 
DOI: $10.7256 / 1811-9018.2015 .9 .16032$

При цитировании этой статьи сноска на доі обязательна

\section{Право и политика 9 (189) • 2015}

Несмотря на текстуальное совпадение, Основы законодательства о судоустройстве 1958 года вкладывают иное, в сравнении с Законом о судоустройстве 1938 года, содержание в осуществление правосудия по уголовным делам.

Согласно пункта «а» статьи 4 Закона «О судоустройстве» 1938 года при рассмотрении уголовных дел задачей суда является применение установленных законом наказаний к «изменникам Родины, вредителям, расхитителям...» и т.п. В пункте «б» статьи 4 Основ законодательства о судоустройстве 1958 года под правосудием понимается рассмотрение уголовных дел и применение «установленных законом мер наказания к лицам, виновным в совершении преступления», либо оправдание невиновных.

Таким образом, в Основах законодательства о судоустройстве 1958 года сформулировано дуалистическое назначение уголовного судопроизводства, подобное имеющемуся в УПК РФ 2001 года. Напротив, в Законе «О судоустройстве» 1938 года второй аспект (частное начало) двуединой задачи уголовного судопроизводства игнорируется.

В отличие от Основ законодательства о судоустройстве 1958 года в Основах уголовного судопроизводства 1958 года [48] термина «цель» нет. Законодатель закрепляет только задачи, которые как указано выше, впервые нашли отражение в процессуальном акте.

В соответствии с Основами уголовного судопроизводства 1958 года и разработанном вслед за ними УПК РСФСР 1960 года [49] задачи уголовного судопроизводства носили как собственно уголовно-процессуальный, так и розыскной характер: быстрое и полное раскрытие преступлений; изобличение виновных; обеспечение правильного применения закона, чтобы каждый совершивший преступление был подвергнут справедливому наказанию, и ни один невиновный не был привлечен к уголовной ответственности и осуждён; укрепление социалистической законности и правопорядка; предупреждение и искоренение преступлений; охрана интересов общества, прав и свобод граждан; воспитание граждан в «духе неуклонного» соблюдения советских законов и правил социалистического общежития.

Сравнение норм статьи 2 «Цели правосудия», статьи 3 «Задачи суда» Основ законодательства о судоустройстве 1958 года, статьи 2 «Задачи уголовного судопроизводства» Основ уголовного судопроизводства 1958 года и УПК РСФСР 1960 года позволяет сделать два вывода. Во-первых, содержание задач уголовного судопроизводства, изложенное в статье 2 Основ уголовного судопроизводства 1958 года и УПК
РСФСР 1960 года, воспроизводит содержание целей и задач, закреплённых в статьях 2,3 Основ законодательства о судоустройстве 1958 года. Во-вторых, в статье 2 Основ уголовного судопроизводства 1958 года и УПК РСФСР 1960 года некоторые задачи не имеют аналогов в Основах законодательства о судоустройстве 1958 года, например, быстрое и полное раскрытие преступлений, изобличение виновных, искоренение и предупреждение преступлений.

В Основах уголовного судопроизводства 1958 года и УПК РСФСР 1960 года легализована идея телеологического плюрализма А. Тагера 1924 года, появившаяся за 34 года до их принятия. Эту идею, как отмечалось выше, затем поддержали М.С. Строгович, Н.Н.Полянский и др., а также сформулировал как систему задач уголовного судопроизводства И.Д. Перлов (1947 год) для проекта союзного УПК.

В действующем УПК РФ 2001 года законодатель отказался от регламентации задач, не свойственных уголовному судопроизводству (быстрое и полное раскрытие, предупреждение и искоренение преступлений и др.), закрепив в назначении лишь его изначальную двойственную природу - публичный и частный аспекты. Такой подход вызвал критику со стороны сторонников советского понимания задач уголовного судопроизводства, которые считают, что тем самым законодатель сделал уголовное судопроизводство аморфным, не нацеленным на результат [50, с. 24-26].

Будучи сторонником понимания уголовного судопроизводства как системы гарантий прав личности, в отношении которой осуществляется уголовное преследование, мы, тем не менее, согласны с логикой рассуждений исследователей, выразивших неприятие новой регламентации задач уголовного процесса.

Введя в уголовно-процессуальный закон ряд новелл, изменив формулировку его назначения, законодатель сохранил советскую систему стадий, и не решил проблему досудебного производства. Что это процессуальная или не процессуальная деятельность? Если процессуальная деятельность, то почему по каждому факту совершения преступления возбуждается уголовное дело? Если деятельность не процессуальная, то почему возбуждение и предварительное расследование являются уголовно-процессуальными стадиями, результаты производства в которых до сих пор предопределяют решение по уголовному делу? Если возбуждение и расследование по каждому факту совершения преступления обязательны, то почему в качестве задач не закрепляется такой результат расследования преступлений, совершённых в условиях неочевидности, 
DOI: $10.7256 / 1811-9018.2015 .9 .16032$

При цитировании этой статьи сноска на doi обязательна

История государства и права

как их раскрытие? Если по каждому факту совершения необходимо возбуждать и расследовать уголовное дело, конечно же, с целью его раскрытия, хотя в уголовнопроцессуальном законе об этом ничего не говорится, то для чего существует оперативно-розыскная деятельность, которая предполагает выявление и пресечение фактов совершения преступлений и т.п.?

Чтобы реформа уголовного судопроизводства состоялась, недостаточно изменить формулировку назначения уголовного судопроизводства и закрепить некоторые прогрессивные институты,

Представляется, что реформа уголовного процесса будет данностью только тогда, когда легальное содержание задач уголовного судопроизводства будет подкреплено кардинальным изменением процессуальной формы, которая в большей степени будет соответствовать изначальному содержанию уголовно-процессуальной деятельности как процедуры разрешения судом уголовно-правового спора по существу!

Ретроспектива понимания и легального закрепления назначения уголовного судопроизводства свидетельство того, что его содержание не меняется, а большее или меньшее присутствие публичного или частного начала его двуединой задачи лишь отражение особенностей социально-экономического развития общества и государства в конкретный исторический период.

Казалось бы, этот теоретический вывод и приведённые выше примеры понимания и легального закрепления задач уголовного судопроизводства не имеют никакого практического значения. Но это отнюдь не так.

Отказ от исконного назначения уголовного судопроизводства как процедуры разрешения уголовноправового спора, произошедший в советский период, имел и имеет печальные для российской уголовной юстиции последствия. Он привел не только к извращению природы уголовного судопроизводства, но и к атрофии оперативно-розыскной деятельности, которая в первую очередь должна быть направлена на раскрытие и предупреждение совершения преступлений. Эти последствия принятием УПК РФ не преодолены и вряд ли смогут быть преодолены в силу его половинчатости, являющейся следствием отсутствия системного подхода к проведению судебной реформы. Вероятно, есть необходимость, наконец-то, продумать концепцию реформы, тщательно разработать совокупность нормативно-правовых актов, определяющими среди которых должны быть судоустройственные, и уже затем провести реформу, а не имитировать её проведение.

\section{Библиография:}

1. Краткое изображение процессов или судебных тяжеб //ПС3 III. T.V (1713-1719). №3006. - СПб.: Тип. II Отделения СЕИВ Канцелярии, 1830. - 782 с.

2. Посошков, И. Т. Книга о скудости и богатстве / И. Т. Посошков; ред. и коммент. Б. Б. Кафенгауза. - М.: Изд-во АН СССР, 1951. $-408 \mathrm{c}$.

3. У Угловно-процессуальный кодекс Российской Федерации от 18.12.2001 N 174-Ф3 (ред. от 29.06.2015) //Собрание законодательства РФ. - 2001. - №52 (ч. І). - Ст. 4921.

4. Фонвизин, Д. И. Избранное / Д. И. Фонвизин; сост., вступ. ст., с. 5-22, и примеч. Ю. В. Стенника; худож. П. А. Савицкий. - М.: Сов. Россия, 1983. - 135 с.

5. Верещагина, А.В. Государственно-правовые воззрения Д.И. Фонвизина / А.В. Верещагина //Российская академия юридических наук. Научные труды. Выпуск 3. Т.І. - М.: 2003. - С.65-73.

6. Десницкий, С. Е. Представление о учреждении законодательной, судительной и наказательной власти в Российской Империи / С. Е. Десницкий // Избранные произведения русских мыслителей второй половины XVIII века: в 3 т. - M.: Госполитиздат, 1952. - Т. 1. - С. 292-332.

7. Неволин, К.А. Энциклопедия законоведения. История философии законодательства/Вступительная статья Д.И. Луковской, С.С. Гречишкина, Ю.В. Ячменева. Подготовка текста С.С. Гречишкина / К.А. Неволин. - СПб.: Издательство С. - Петербургского государственного университета, 1997. - 400 с.

8. Сперанский, М.М. О коренных законах государства/ М.М. Сперанский //Сперанский М.М. Проекты и записки / Подготовили к печати А.И. Копанев и М.В. Кукушкина; Под ред. С.Н.Валка. - М. - Л.: Изд-во АН СССР, $1961 .-244$ с.

9. Баршев, Я.И. Основания уголовного судопроизводства с применением к российскому уголовному судопроизводству /Я.И. Баршев-М.: «ЛекстЭст», 2001. - 240 с.

10. Линовский, В.А. Опыт исторических розысканий о следственном уголовном судопроизводстве в России / В.А. Линовский. - М.: «ЛексЭст», 2001. - 240 с.

11. Бентам, И. О судоустройстве /И.Бентам. - СПб.: Типогрфия Правительствующего Сената. 1860. - 224 с.

12. Основные положения преобразования судебной части в России. - М.: Типография В. Готье, $1863 .-111$ с.

13. Фойницкий, И.Я. Курс уголовного судопроизводства. Т.ІІ. / И.Я. Фойницкий. - Петроград, Типография «Двигатель», 1915. - 608 c.

14. Викторский, С.И. Русский уголовный процесс. - Учебное пособие/С.И. Викторский. - М.: Юридическое бюро «Городец», 1997. -448 с. 
DOI: $10.7256 / 1811-9018.2015 .9 .16032$

При цитировании этой статьи сноска на dоі обязательна

\section{Право и политика $9(189) \cdot 2015$}

15. Михайловский, И.В. К вопросу об уголовном судье. По поводу предстоящей судебной реформы / И.В. Михайловская. Нежин, Тип. - Лит. М.В. Глезера, 1899. - 92 с.

16. К Кожевников, М.В. История советского суда/Под редакцией И.Т. Полякова /М.В. Кожевников. - М.: Юриздат, 1948. -376 с.

17. Ленин, В.И. Очередные задачи Советской власти (извлечение) //История Советской прокуратуры в важнейших документах. Под редакцией и с предисловием Зам. Генерального Прокурора СССР К.А. Мокичева /В.И. Ленин. - М.: Госюриздат, 1952. - С.51.

18. Декрет СНК РСФСР №1 о суде от 24 ноября 1917 года //СУ РСФСР. - 1917. - №4. - Ст. 50.

19. Инструкции НКЮ РСФСР «О революционном трибунале, его составе, делах, подлежащих его ведению, налагаемых им наказаниях и о порядке ведения его заседаний» от 19 декабря 1917 года//СУ. - 1917. - №12. - Ст.170.

20. Декрет СНК РСФСР «О взяточничестве» от 8 мая (25 апреля) 1918 года //СУ РСФСР. - 1918. - №35. - Ст. 467.

21. Декрета ВЦИК и СНК «О мерах борьбы с хищениями из государственных складов и должностными преступлениями, способствующими хищениям» от 1 июня 1921 года //СУ РСФСР. - 1921. - №49. - Ст. 262.

22. Декрета СНК РСФСР «Об устранении волокиты» от 20 декабря 1919 года//СУ РСФСР. - 1920. - №1. - Ст. 7.

23. Резолюция о Всероссийской Чрезвычайной Комиссии. Принята IX Всероссийским Съездом Советов //СУ РСФСР. 1922. - №4. - Ст. 42.

24. Резолюция одиннадцатой Всероссийской Конференции РКП (б). 19-22 декабря 1921 года «Очередные задачи партии в связи с восстановлением хозяйства»//История Советской прокуратуры в важнейших документах. Под редакцией и с предисловием Зам. Генерального Прокурора СССР К.А. Мокичева. - М.: Госюриздат, 1952. - С.253.

25. Тагер, А. О предмете и пределах науки об уголовном суде / А. Тагер//Право и жизнь. - 1924. - №1. -С. 50-74.

26. Строгович, М. Принципы советского уголовного процесса /М. Строгович //Советское право. - 1927. - №1 (25). - С. 92-111.

27. Реформа советского уголовного процесса. Прения по докладу Н.В. Крыленко и заключительные слова Н.В. Крыленко и А.Я. Эстрина//Революция права. - 1928. - №2. - С. 67-93.

28. Постышев П. Основные задачи советской юстиции на современном этапе. Выправленная и дополненная стенограмма речи на VI совещании руководителей работников органов юстиции. 13 февраля 1932 года//Советское государство. 1932. - №2. - С.3-18.

29. Полянский, Н. Н. Советский суд / Н. Н. Полянский // Советское государство и право. - 1947. - № 1. - С. 61-72.

30. Перлов, И. Д. К проекту уголовно-процессуального кодекса Союза ССР / И. Д. Перлов // Советское государство и право. - 1947. - № 7. - С. 43-52.

31. Элькинд, П.С. Цели и средства их достижения в советском уголовно-процессуальном праве /П.С. Элькинд. - Л.: Издательство Ленинградского университета, 1976. - 143 с.

32. Конституция (Основной Закон) Российской Социалистической Федеративной Советской Республики. Принята $\mathrm{V}$ Всероссийским съездом Советов в заседании от 10 июля 1918 года //СУ РСФСР. - 1918. - №51. - Ст. 582.

33. Конституция (Основной Закон) Российской Социалистической Федеративной Советской республики. Утверждена Постановлением XII Всероссийского Съезда Советов от 11 мая 1925 года «Об утверждении текста Конституции (Основного Закона) РСФСР //СУ РСФСР. - 1925. - №30. - Ст. 218.

34. Основной закон (Конституция) Союза Советских Социалистических Республик. Принята второй сессией цИК СССР первого созыва 6 июля 1923 года и в окончательно редакции II съездом Советов СССР 31 января 1924 года. - М.: Изд. ЦИК СССР, 1924.

35. Конституция (Основной Закон) Союза Советских Социалистических Республик. Утверждена Чрезвычайным VIII съездом Советов Союза ССР 5 декабря 1936 года // Известия ЦИК СССР и ВЦИК. - 1936. - N 283.

36. Конституция (Основной Закон) Российской Советской Федеративной Социалистической Республики. Принята Постановлением Чрезвычайным XVII Всероссийским Съездом Советов от 21 января 1937 года. Режим доступа: //http:// base.consultant.ru/cons/cgi/online.cgi?req=doc;base=ESU;3228;fld=134 ( дата обращения: 04.05. 2015).

37. Конституция (Основной Закон) Союза Советских Социалистических Республик. Принята на внеочередной седьмой сессии ВС СССР девятого созыва 7 октября 1977 года //Правда. - 1977. -8 октября.

38. Конституция (Основной Закон) Российской Советской Федеративной Социалистической Республики. Принята на внеочередной седьмой сессии ВС РСФСР девятого созыва 12 апреля 1978 года //Ведомости ВС РСФСР. - 1978. - №15. - Ст. 407.

39. Положение о народном суде Российской Социалистической Федеративной Советской Республики. Декрет Всероссийского Центрального Исполнительного Комитета от 21 октября 1920 года // СУ РСФСР. - 1920. - № 83. - Ст. 407.

40. Положение о судоустройстве РСФСР. Введено в действие Постановлением Всероссийского Центрального Исполнительного Комитета «О введении в действие Положения о судоустройстве РСФСР» от 11 ноября 1922 года //СУ РСФСР. - 1922. №69. - Ст. 902.

41. Основы судоустройства Союза ССР и союзных республик. Приняты 2 сессией ЦИК СССР в октябре 1924 года//СЗ СССР. - 1924. - Ст. 203.

42. Положение о судоустройстве РСФСР. Утверждено Постановлением ВЦИК «Об утверждении Положения о судоустройстве РСФСР» от 19 ноября 1926 года//СУ РСФСР. - 1926. - №85. - Ст. 624.

43. Закон СССР от 16.08.1938 «О судоустройстве СССР, союзных и автономных республик» //Ведомости ВС СССР. - 1938-N 11.

44. Александров, А.С., Александрова, И.А., Круглов, И.В. Назначение уголовного судопроизводства и наказания /А.С. Александров, И.А. Александров, И.В. Круглов. - Нижний Новгород: Нижегородская правовая академия, 2006. - 111 с.

45. Постановление ВЦИК от 25.05.1922 «Об Уголовно-Процессуальном Кодексе» (вместе с «Уголовно-Процессуальным Кодексом Р.С.Ф.С.Р.») // СУ РСФСР», 1922, N 20-21, ст. 230. 
DOI: $10.7256 / 1811-9018.2015 .9 .16032$

При цитировании этой статьи сноска на dоі обязательна

История государства и права

46. Уголовно-процессуальный кодекс РСФСР. Утвержден Постановлением ВЦИК от 15 февраля 1923 года//СУ РСФСР. 1923. - №7. - Ст.106.

47. Основы уголовного судопроизводства Союза ССР и союзных республик. Утверждены Постановлением Президиума ЦИК СССР от 31 октября 1924 года//С3 СССР. - 1924. - №24. - Ст. 206.

48. Основы уголовного судопроизводства Союза ССР и союзных республик. Утверждены Законом СССР «Об утверждении Основ уголовного судопроизводства Союза ССР им союзных республик» от 25 декабря 1958 года//Ведомости ВС СССР. - 1959. - №1. - Ст. 15.

49. Уголовно-процессуальный кодекс РСФСР от 27 октября 1960 года //Ведомости ВС РСФСР. - 1950-. - №40. - Ст.592.

50. Баранов А.М., Деришев Ю.В., Николаев Ю.А. Понятие и назначение уголовного судопроизводства. Источники уголовно-процессуального права: учебное пособие /А.М. Баранов, Ю.В. Деришев, Ю.А. Николаев. - Омск: Юридический институт, 2003. - 49 с.

\section{References (transliterated):}

1. Pososhkov, I. T. Kniga o skudosti i bogatstve / I. T. Pososhkov; red. i komment. B. B. Kafengauza. - M.: Izd-vo AN SSSR, 1951. $-408 \mathrm{~s}$.

2. Fonvizin, D. I. Izbrannoe / D. I. Fonvizin; sost., vstup. st., s. 5-22, i primech. Yu. V. Stennika; khudozh. P. A. Savitskii. - M.: Sov. Rossiya, 1983. - $135 \mathrm{~s}$.

3. Vereshchagina, A.V. Gosudarstvenno-pravovye vozzreniya D.I. Fonvizina / A.V. Vereshchagina //Rossiiskaya akademiya yuridicheskikh nauk. Nauchnye trudy. Vypusk 3. T.I. - M.: 2003. - S. 65-73.

4. Desnitskii, S. E. Predstavlenie o uchrezhdenii zakonodatel'noi, suditel'noi i nakazatel'noi vlasti v Rossiiskoi Imperii / S. E. Desnitskii // Izbrannye proizvedeniya russkikh myslitelei vtoroi poloviny XVIII veka: v 3 t. - M.: Gospolitizdat, 1952. - T. 1. - S. $292-332$.

5. Nevolin, K.A. Entsiklopediya zakonovedeniya. Istoriya filosofii zakonodatel'stva/Vstupitel'naya stat'ya D.I. Lukovskoi, S.S. Grechishkina, Yu.V. Yachmeneva. Podgotovka teksta S.S. Grechishkina/K.A. Nevolin. - SPb.: Izdatel'stvo S. - Peterburgskogo gosudarstvennogo universiteta, 1997. - $400 \mathrm{~s}$.

6. Speranskii, M.M. O korennykh zakonakh gosudarstva/ M.M. Speranskii //Speranskii M.M. Proekty i zapiski / Podgotovili k pechati A.I. Kopanev i M.V.Kukushkina; Pod red. S.N.Valka. - M. - L.: Izd-vo AN SSSR, 1961. - 244 s.

7. Barshev, Ya.I. Osnovaniya ugolovnogo sudoproizvodstva s primeneniem k rossiiskomu ugolovnomu sudoproizvodstvu / Ya.I. Barshev-M.: «LekstEst», 2001. - 240 s.

8. Linovskii, V.A. Opyt istoricheskikh rozyskanii o sledstvennom ugolovnom sudoproizvodstve v Rossii / V.A. Linovskii. - M.: «LeksEst», 2001. - 240 s.

9. Bentam, I. O sudoustroistve /I.Bentam. - SPb.: Tipogrfiya Pravitel'stvuyushchego Senata. 1860. - 224 s.

10. Foinitskii, I.Ya. Kurs ugolovnogo sudoproizvodstva. T.II. / I.Ya. Foinitskii. - Petrograd, Tipografiya «Dvigatel'», 1915. - 608 s.

11. Viktorskii, S.I. Russkii ugolovnyi protsess. - Uchebnoe posobie /S.I. Viktorskii. - M.: Yuridicheskoe byuro «Gorodets», 1997. $-448 \mathrm{~s}$.

12. Mikhailovskii, I.V. K voprosu ob ugolovnom sud'e. Po povodu predstoyashchei sudebnoi reformy/ I.V. Mikhailovskaya. - Nezhin, Tip. - Lit. M.V. Glezera, 1899. - 92 s.

13. Kozhevnikov, M.V. Istoriya sovetskogo suda/Pod redaktsiei I.T. Polyakova /M.V. Kozhevnikov. - M.: Yurizdat, 1948 . - 376 s.

14. Lenin, V.I. Ocherednye zadachi Sovetskoi vlasti (izvlechenie)//Istoriya Sovetskoi prokuratury v vazhneishikh dokumentakh. Pod redaktsiei i s predisloviem Zam. General'nogo Prokurora SSSR K.A. Mokicheva /V.I. Lenin. - M.: Gosyurizdat, 1952. - S.51.

15. Tager, A. O predmete i predelakh nauki ob ugolovnom sude / A. Tager//Pravo i zhizn'. - 1924. - №1. -S. 50-74.

16. Strogovich, M. Printsipy sovetskogo ugolovnogo protsessa /M. Strogovich //Sovetskoe pravo. - 1927. - №1 (25). - S. 92-111.

17. Postyshev P. Osnovnye zadachi sovetskoi yustitsii na sovremennom etape. Vypravlennaya i dopolnennaya stenogramma rechi na VI soveshchanii rukovoditelei rabotnikov organov yustitsii. 13 fevralya 1932 goda//Sovetskoe gosudarstvo. - 1932. - №2. - S.3-18.

18. Polyanskii, N. N. Sovetskii sud / N. N. Polyanskii // Sovetskoe gosudarstvo i pravo. - 1947. - № 1. - S. 61-72.

19. Perlov, I. D. K proektu ugolovno-protsessual'nogo kodeksa Soyuza SSR / I. D. Perlov // Sovetskoe gosudarstvo i pravo. - 1947. - № 7. - S. 43-52.

20. El'kind, P.S. Tseli i sredstva ikh dostizheniya v sovetskom ugolovno-protsessual'nom prave /P.S. El'kind. - L.: Izdatel'stvo Leningradskogo universiteta, 1976. - $143 \mathrm{~s}$.

21. Zakon SSSR ot 16.08.1938 "O sudoustroistve SSSR, soyuznykh i avtonomnykh respublik" //Vedomosti VS SSSR. - 1938-N 11.

22. Aleksandrov, A.S., Aleksandrova, I.A., Kruglov, I.V. Naznachenie ugolovnogo sudoproizvodstva i nakazaniya /A.S. Aleksandrov, I.A. Aleksandrov, I.V. Kruglov. - Nizhnii Novgorod: Nizhegorodskaya pravovaya akademiya, 2006. - $111 \mathrm{~s}$.

23. Baranov A.M., Derishev Yu.V., Nikolaev Yu.A. Ponyatie i naznachenie ugolovnogo sudoproizvodstva. Istochniki ugolovnoprotsessual'nogo prava: uchebnoe posobie /A.M. Baranov, Yu.V. Derishev, Yu.A. Nikolaev. - Omsk: Yuridicheskii institut, 2003. $-49 \mathrm{~s}$ 